\title{
KOMPETENSI, PENGALAMAN, DAN PEMBELAJARAN INOVASI YANG MEMENGARUHI KEMAMPUAN BERINOVASI DAN SUKSES KEWIRAUSAHAAN
}

\author{
Brata Wibawa Djojo \\ Management Department, School of Business Management, BINUS University \\ Jln K.H. Syahdan No. 9, Palmerah, Jakarta Barat 11480 \\ brata@binus.ac.id
}

\begin{abstract}
Entreprneurship is one of economic indicator in a country, whereas the entrepreneur would make a job impact to many people. Entrepreneurship could not be implemented without the willingness and capability to make effort. An entrepreneur must have a vision of business opportunities as well, especially in health industry in Indonesia in forthcoming days. The question is on how an entrepreneur could success in health business relating to his or her competencies, experiences, and innovation learning in which also affect innovation capability. This paper studies about some successful Indonesian entrepreneurs in health business whom make an inspiration and input to entrepreneur candidates or existing entrepreneurs. This paper is supported by theoretical review to find the research model's variables for future research, which might be in empirical study. This paper used judgement sampling method to Indonesian entrepreneurs in health business. The interesting issue is that the competency and success of the entrepreneurs do not always relate to formal education they got, but how the entrepreneurs implement the innovation way in their business. There are some gaps in this paper, whereas how the similiar research could take a good sample and exploit the research design well in the future to get a good and accurate research.
\end{abstract}

Keywords: competency, experience, innovation learning, innovation capability, success in entrepreneurship

\begin{abstract}
ABSTRAK
Kewirausahaan merupakan salah satu pendorong perekonomian suatu negara yang di dalamnya para wirausaha atau pengusaha membuka lapangan pekerjaan bagi banyak orang. Kewirausahaan tidak terjadi begitu saja tanpa adanya kemauan dan kemampuan untuk berusaha. Seorang pengusaha juga dituntut untuk dapat melihat peluang bisnis dengan baik dan cepat, terutama melihat peluang bisnis kesehatan di Indonesia mendatang. Yang menjadi pertanyaan adalah jika seorang pengusaha dapat sukses berwirausaha di bidang kesehatan dengan melihat dari kompetensi, pengalaman dan pembelajaran inovasi yang juga memengaruhi kemampuan berinovasi. Penulisan ini mengupas studi kasus para pengusaha di bidang kesehatan di Indonesia yang telah sukses, sehingga diharapkan dapat memberikan inspirasi dan masukan bagi calon pengusaha atau pengusaha yang sudah ada. Pembahasan secara kualitatif didukung oleh landasan teoretis dalam mencari variabel dalam model penelitian selanjutnya, yang dapat dilakukan secara empiris kuantitatif. Pengambilan sampel menggunakan metode judgement sampling terhadap beberapa pengusaha kesehatan di Indonesia. Yang menarik adalah terhadap studi kasus yang diangkat, kompetensi dan kesuksesan pengusaha tidak selalu mempunyai hubungan dengan tingkat pendidikan formal yang dilaluinya namun bagaimana pengusaha itu dapat melakukan inovasi dan menerapkannya. Gap yang ada pada penulisan ini adalah bagaimana penelitian kuantitatif dengan pengambilan sampel dan model penelitian perlu didesain lebih mendalam agar mendapatkan hasil yang baik dan benar.
\end{abstract}

Kata kunci: kompetensi, pengalaman, pembelajaran inovasi, kemampuan berinovasi, sukses berwirausaha 


\section{PENDAHULUAN}

Topik yang hangat dibicarakan saat ini di Indonesia adalah kewirausahaan, yaitu tingkat pengusaha atau wirausahawan di Indonesia dapat berkembang sesuai harapan. Masalah kewirausahaan tidak terlepas dari faktor internal dan eksternal, antara lain tentang individu memiliki kemampuan dan kemauan untuk berusaha dan mengembangkan talentanya sehingga dapat memberikan kesejahteraan bagi orang banyak, termasuk kreativitas, kepemimpinan, inovasi, kemampuan manajerial. Hal ini juga tidak terlepas dari peran pemerintah atau regulator setempat untuk mendorong pertumbuhan usaha kecil menengah dalam suatu komunitas.

Untuk bidang indusri kesehatan, beberapa sektor swasta dan pengusaha mulai melirik industri ini. Karena dengan adanya isu SJSN (Sistem Jaminan Sosial Nasional) di bidang kesehatan, memacu adrenalin para pengusaha untuk mendirikan usaha yang sejalan dengan isu strategis tersebut. Beberapa pengusaha yang bergerak di bidang kesehatan dan asuransi kesehatan mulai mengantisipasi hal tersebut, terutama sektor swasta yang memiliki beberapa anak perusahaan dan pasar captive. Beberapa uji coba program jaminan kesehatan diterapkan kepada para karyawan di seluruh anak perusahaan untuk mengantisipasi budget. Salah satunya adalah dengan menerapkan program managed care, yaitu penanganan kesehatan terpadu yang melibatkan penyedia kesehatan (provider), sekelompok dokter praktisi, karyawan, pasien pemegang polis asuransi kesehatan, dan rumah sakit dengan sistem yang terintegrasi (Rognehaugh, 1998).

Akan diterapkannya SJSN Kesehatan memungkinkan terciptanya peluang bisnis baru atau pasar baru dengan melakukan inovasi baru, terutama di industri terkait. Beberapa industri tersebut adalah industri farmasi terhadap kebutuhan ketersediaan obat generik dan obat resep yang memiliki khasiat yang baik dengan harga terjangkau, industri rumah sakit terhadap kebutuhan layanan kesehatan dengan harga terjangkau, industri asuransi terhadap kebutuhan produk asuransi kesehatan dasar maupun top-up dengan harga terjangkau dan mekanisme pengumpulan iuran (premi) anggota, dan pendukung usaha lainnya seperti distributor farmasi, klinik, penyedia jasa administrasi, keagenan asuransi, jasa pendidikan atau konsultasi dan penyedia jasa layanan kesehatan atau pendukung lainnya. Pada dasarnya, seseorang pengusaha sejati dapat melihat peluang bisnis dalam segala situasi. Hal ini yang juga dilihat oleh beberapa pengusaha dalam mengantisipasi program SJSN Kesehatan. Gelombang SJSN yang akan diterapkan dapat menciptakan peluang bisnis di sektor jasa kesehatan (healthcare). Yang menarik adalah apakah seorang individu yang memiliki minat berwirausaha di bidang jasa kesehatan dapat menjadi pengusaha sukses meskipun belum ada pengalaman atau kompetensi di bidang itu. Maka dari itu, hal tersebut akan menjadi kajian yang dapat ditelaah lebih lanjut dalam pembahasan secara kualitatif.

Tujuan dari artikel adalah untuk membahas hubungan antara kompetensi, pengalaman, dan pembelajaran inovasi sehingga dapat memengaruhi kemampuan berinovasi dan kesuksesan dalam berwirausaha. Sehingga dari kajian secara teoretis dan studi kasus berdasarkan pengalaman beberapa pengusaha di Indonesia dapat memberikan gambaran dan masukan bagi para pemula untuk berwirausaha pada bidang yang akan digeluti. Terlepas dari banyaknya populasi atau informasi yang tersedia, artikel membatasi pembahasan sebagai berikut: artikel hanya membahas masalah kualitatif berdasarkan pengalaman berinovasi dari sampel yang diambil; sampel yang diambil menggunakan judgement sampling dengan data sekunder, yaitu data yang ada dalam literatur atau materi penulisan yang telah ada sebelumnya sehingga keabsahan informasi dan atau data terhadap sampel mengacu pada literatur atau sumber referensi; model penelitian, termasuk variabel dan subvariabel sebagai pemicu untuk penelitian empiris selanjutnya; tidak dilakukan pengujian validitas, reliabilitas, atau pengujian statistik/kuantitatif lainnya. 


\section{Tinjauan Literatur}

Seorang pengusaha sukses dapat dilihat dari kemampuannya untuk berinovasi. Dalam melakukan model pendekatan terhadap penelitiannya, Howard (2009) mengacu pada model Knowledge to Innovate (2009) dalam menilai kemampuan untuk berinovasi. Kemampuan itu menilai dari tujuh dimensi: kolaborasi, lingkungan, keuangan, pengetahuan, manajemen senior, risiko, dan staf dengan lima tingkat kematangan: (i) komitmen, (ii) dapat menempatkan proses pada tempatnya, (iii) monitor aktivitas, (iv) memiliki tujuan yang SMART (specific, measurable, achievable, reasonable, timeable), dan (v) peningkatan kinerja berkesinambungan.

Inovasi diperlukan untuk mendukung pencapaian tujuan organisasi dengan tingkat kinerja yang memuaskan. Dalam melakukan inovasi, diperlukan suatu kompetensi yang harus dimiliki oleh pengusaha. Teori kompetensi yang pertama kali diperkenalkan oleh McClelland (1973) sebagai alat pengukuran kinerja sebagai penolakan terhadap kemampuan akademis (Howard, 2009). Pencapaian kinerja sehubungan dengan kompetensi dapat dibagi menjadi enam tingkat pencapaian (Benner dalam Howard, 2009): (1) Tingkat 0 - Unskilled/Not Relevant, seorang individu yang tidak dapat menunjukkan kinerja yang baik walaupun dalam instruksi atau keahlian tidak dibutuhkan dalam tahap ini; (2) Tingkat 1 - Novice, seorang individu yang tidak memiliki atau memiliki sedikit pengalaman dalam bidangnya, namun dapat menunjukkan kinerja yang baik jika dalam instruksi atau pedoman yang jelas; (3) Tingkat 2 - Learner, seorang individu yang memiliki beberapa pengalaman dalam bidangnya dan dapat menunjukkan kinerja dengan sedikit pengawasan namun tetap memerlukan instruksi reguler atau pedoman jika situasi baru muncul; (4) Tingkat 3 - Kompeten, seorang individu yang dapat menunjukkan kinerja dalam bidangnya dan dapat bekerja secara efektif tanpa pengawasan dari hari ke hari namun mungkin memerlukan instruksi, pedoman atau dukungan sewaktu-waktu ketika berhadapan dengan situasi yang tidak biasa; (5) Tingkat 4 - Proficient (terampil dalam bidangnya), seorang indvidu yang memiliki pengalaman yang kaya dan hanya memerlukan pengawasan secara manajerial serta mampu menunjukkan keahliannya kepada yang lain; (6) Tingkat 5 - Expert (sangat terampil dalam bidangnya dengan beberapa tahun pengalaman), seorang individu yang memiliki intuisi dan tidak membutuhkan pengawasan dari yang lain selain clinical governance, ia bertindak sebagai mentor dan inovator dalam bidangnya.

Ketika terjadi gap antara keahlian yang dibutuhkan dengan keahlian yang dimiliki, perlu dilakukan suatu tindakan edukasi untuk meningkatkan kinerja yang dibutuhkan atau tujuan yang diharapkan (Howard, 2009). Edukasi dan training harus difokuskan sesuai kebutuhan yang diinginkan. Jika edukasi dan training telah dilakukan, diharapkan akan tercipta kemampuan berinovasi dari individu atau pengusaha bersangkutan sehingga ketika tercapai tujuan yang telah ditetapkan.

Model Benner (Benner dalam Howard, 2009) menggarisbawahi beberapa tahapan untuk menjadi praktisi terampil berdasarkan tiga aspek dalam keseluruhan kinerja, yaitu: pertama, perubahan paradigma dari aturan abstrak kepada pengalaman hidup sebagai dasar perilaku; kedua, perubahan persepsi terhadap situasi, dari sekumpulan bagian yang terpisah menjadi entitas lengkap yang beberapa bagian lebih relevan atau lebih penting dari yang lain; ketiga, pergerakkan dari detached observer menjadi involved performer. Dengan menggunakan model Benner, kinerja terampil tidak hanya diukur dari hasil ataupun perilaku, tetapi dari keduanya termasuk cara seorang individu memproses informasi sebelum bertindak dan cara mereka bertindak untuk mencapai hasil yang diinginkan (Howard, 2009).

Dalam argumentasi yang disampaikan, Alegre dan Chiva (2007) mengatakan bahwa sebelum organisasi melakukan inovasi secara efektif, organisasi tersebut harus menjadi sebuah organisasi pembelajar terlebih dahulu. Dalam penelitian yang mereka lakukan di industri keramik di negara Uni Eropa pada bulan Juni hingga September 2004, mereka mengidentifikasikan lima karakteristik penting yang dibutuhkan untuk menciptakan organisasi yang berkinerja tinggi dan berinovasi. Lima 
karakteristik tersebut yaitu (i) pengalaman, sehingga dapat menghasilkan ide terhadap kreativitas dengan baik; (ii) berani mengambil risiko, berhubungan dengan toleransi ambigu, ketidakpastian, dan tingkat kesalahan; (iii) interaksi dengan lingkungan eksternal, yaitu faktor di luar kontrol organisasi; (iv) dialog, yang berupa kumpulan pertanyaan menjadi proses, asumsi dan jawaban kepastian; (v) dan pengambilan keputusan secara partisipasi, yang dapat memberikan efek motivasi. Dialog merupakan cara terbaik dalam menyebarkan informasi dan keterampilan dalam organisasi dan menciptakan banyak pandangan (Alegre \& Chiva, 2007).

Kinerja individu bukan hanya sebagai alat yang diperlukan dalam seluruh aspek peran mereka namun lebih berdasarkan pada situasional dan pengalaman. Kinerja dalam area tertentu akan diperlukan pada jenjang berbeda tergantung dari pengetahuan teoretis dan pengalaman sebelumnya dari seorang individu (Howard, 2009). Penelitian sebelumnya menggunakan pendekatan ini terhadap inovasi dalam pencatatan record pasien secara elektronik di industri kesehatan (Department of Health dalam Howard, 2009).

Pendidikan kewirausahaan tidak memiliki dampak langsung terhadap intensi dan karir pengusaha, sebagaimana penelitian yang dilakukan oleh Matlay; Ramayah \& Zainon; Souitaris, dkk dalam Ramayah, Ahmad, dan Fei (2012). Dalam penelitian lain yang dilakukan oleh Solomon sebagaimana dikutip oleh Kirby dalam Ramayah, Ahmad, dan Fei (2012): "Pelajaran kewirausahaan didesain untuk memperkenalkan mahasiswa untuk menjadi karyawan yang baik, ketimbang menjadi seorang pengusaha yang sukses.” Penelitian yang sama dilakukan oleh Cheng, dkk dalam Ramayah, Ahmad, dan Fei (2012), bahwa kebanyakan pelajaran kewirausahaan (84,4\%) diberikan oleh dosen dan hanya memberikan sedikit kesempatan bagi mahasiswa untuk mengembangkan keterampilan kewirausahaan, yang seharusnya hal tersebut dapat memberikan kesempatan bagi mahasiswa untuk mengembangkan keterampilan, atribut, dan perilaku untuk menjadi pengusaha yang sukses (Kirky dalam Ramayah, Ahmad, \& Fei, 2012). Pendidikan kewirausahaan dapat dimulai sejak dini pada sekolah dasar dan sekolah menengah. Pendidikan kewirausahaan dan eksposurnya harus didorong pada setiap kesempatan yang memugkinkan dan ditekankan sedini mungkin (Ramayah, Ahmad, \& Fei, 2012).

Dalam penelitian yang dilakukan oleh Jean Lave (Reuber, 1994) terhadap para penerus bisnis yang memiliki budaya berbeda, dikatakan bahwa pembelajaran muncul melalui partisipasi dan keikutsertaan dalam komunitas praktisi. Nilai-nilai yang ada di dalamnya, seperti sosial, budaya, dan konteks pengalaman masa lalu menjadi hal yang penting dalam pembelajaran dan bagaimana meningkatkan kinerja (Reuber, 1994). Dalam penelitiannya terhadap pengusaha wanita di Kanada, Reuber (1994) mengatakan bahwa wanita pengusaha yang memiliki pengalaman akan lebih sukses ketimbang wanita yang kurang pengalaman di dalam menjalankan bisnisnya. Penelitian tersebut menginvestigasikan bahwa ada tiga tipe aktivitas yang berbeda pada suatu perusahaan: inovasi, perencanaan dan budgeting, dan internasionalisasi. Wanita pengusaha yang berpengalaman di pemasaran dapat menciptakan produk baru dan jasa dalam kurun waktu dua tahun, sebab pengalaman di bidang pemasaran memiliki keterkaitan terhadap pengembangan produk atau inovasi. Wanita pengusaha yang berpengalaman di pasar internasional dapat lebih cepat mendirikan bisnisnya dan memiliki persentase penjualan lebih besar dari luar Kanada. Lebih lanjut, makin banyak pengalaman dan pendidikan yang dimiliki oleh wanita pengusaha dalam pemasaran, manajemen keuangan, dan pasar internasional, maka makin baik perencanaan dan budgeting yang dilakukan olehnya (Reuber, 1994).

Kriteria sukses bisa diartikan dalam berbagai macam cara. Ada yang mengartikan sukses adalah jika sudah mencapai tujuan atau hal yang diinginkan. Ada yang mendefiniskan sukses dari ukuran ekonomi seperti profit, pertumbuhan penjualan atau karyawan, dan ukuran besar-kecilnya perusahaan. Cuba, Decenzo, dan Anish (dalam Claire-Woldt, 2005) mengatakan bahwa bisnis yang sukses jika telah dapat berjalan selama lima tahun. Dalam studi kesuksesan pada pengusaha Amerika 
dan Kroasia, sukses diukur jika profit perusahaan berada di atas profit rata-rata industri (Lussier dan Pfeifer's dalam Claire-Woldt, 2005).

Kesuksesan suatu organisasi pernah diteliti oleh Kalleberg dan Leicht (dalam Claire-Woldt, 2005) pada 400 perusahaan di bidang komputer, makanan dan minuman, dan industri kesehatan. Yang menarik dalam penelitian tersebut adalah menghubungkan kesuksesan dengan kelangsungan hidup. Pada penelitian tersebut ditemukan bahwa usia organisasi, penggabungan, menjadi industri yang berkembang, fokus pada kualitas dan kepercayaan diri pemilik terkait positif dengan kelangsungan hidup. Sementara, keterlibatan pemilik dalam bisnis lain dan inovasi terkait secara negatif dengan kelangsungan hidup. Hanya ukuran organisasi dan penggabungan terkait secara positif dengan kesuksesan, dan pemilik yang usianya senior mempunyai keterkaitan kecil dengan pengalaman kesuksesan bisnis (ditinjau dari pertumbuhan pendapatan). Dalam tulisannya di surat kabar (Caroll dan Huo dalam Claire-Woldt, 2005), lingkungan insitusional memiliki efek kuat pada kelangsungan hidup, sedangkan lingkungan pekerjaan memiliki efek kuat terhadap sukses. Motivasi seorang pengusaha dalam menjalankan bisnisnya lebih pada motivasi ekonomi (Campbell dalam Claire-Woldt, 2005), sehingga pengusaha dikatakan sukses jika ia dapat mencapai kesuksesan dalam ekonomi. Dalam penelitian terhadap pemilik bisnis di Indiana (Kalleberg \& Leicht's dalam Claire-Woldt, 2005), sukses dapat didefiniskan dalam indikator kinerja keuangan dan akunting serta evaluasi pemilik kepentingan terhadap kinerja.

Fokus usaha di perusahaan mikro (microenterprise) befokus pada pertumbuhan karyawan, pengentasan kemiskinan, dan pertumbuhan finansial. Dalam penelitian terhadap pengusaha microenterprise wanita di Asia Selatan, kekuasaan yang dimiliki oleh pengusaha wanita dapat dijadikan sebagai indikator kesuksesan ketimbang pengukuran di bidang ekonomi (Kantor dalam Claire-Woldt, 2005). Penelitian terhadap perusahaan Jerman, kesuksesan diukur dari cara perusahaan dapat menempatkan profit jangka panjang dengan pencapaian yang tinggi dalam return on assets. Sedangkan pada perusahaan di Jerman Utara, sukses diukur dari pertumbuhan penjualan sehingga dapat bersaing antarperusahaan di Eropa. Perusahaan Anglo (baik Amerika maupun Inggris), menempatkan prioritas tertinggi pada tingkat pengembalian penjualan atau return on sales sebagai bagian dari budaya yang berorientasi pada jangka pendek (Hegerty \& Hoffman dalam Claire-Woldt, 2005). Penelitian yang dilakukan oleh Hewitt-Dundas (2006) pada pabrik kecil dan besar didapat hasil bahwa inisiatif untuk menghasilkan inovasi pada pabrik kecil terletak pada peluang networking, program pengurangan biaya, dan strategi pemasaran dalam menghasilkan marjin profit pada produk baru, sumber daya manusia pada implementasi perubahan, dan akses mudah terhadap teknologi informasi. Sedangkan pada perusahaan besar adalah meminimalkan risiko pada pengembangan dan peningkatan akses menjadi spesialis (Hewitt-Dundas, 2006).

\section{METODE}

Kompetensi, pengalaman, dan pembelajaran inovasi dari seorang pengusaha dapat memengaruhi kesuksesan dalam berwirausaha atau keberlangsungan hidup organisasi, selain memengaruhi kemampuan berinovasi. Kompetensi, pengalaman, dan pembelajaran inovasi dapat dijadikan sebagai variabel bebas jika akan dilakukan penelitian secara empiris. Sedangkan kemampuan berinovasi yang dipengaruhi oleh kompetensi, pengalaman, dan pembelajaran inovasi juga dapat memengaruhi keberlangsungan hidup organisasi atau kesuksesan dalam berwirausaha sehingga dapat dijadikan sebagai variabel moderating.

Dalam kebanyakan penelitian kewirausahaan, keberlangsungan hidup organisasi sebagai variabel terikat, jarang yang meneliti kesuksesan sebagai variabel terikat (Claire-Woldt, 2005). Namun dalam penelitiannya, Claire-Woldt (2005) mengidentifikasikan beberapa peneliti sebelumnya telah 
menggunakan kesuksesan sebagai variabel terikat, seperti Cuba, Decenzo dan Anish (1983), Lussier dan Pfeifer's (2000), Kalleberg dan Leicht (1991), Caroll dan Huo (1986), Campbell (1992), Kantor (2002), Hegerty dan Hoffman (1990), Hewitt-Dundas (2006). Sehingga penulisan ini mengusulkan agar keberlangsungan hidup atau kesuksesan dalam berwirusaha menjadi variabel terikat.

Dalam artikel ini sampel yang dipilih adalah berdasarkan judgement sampling. Sampel dipilih berdasarkan penilaian peneliti bahwa dia adalah pihak yang paling baik untuk dijadikan sampel penelitian walaupun mungkin masih ada pihak lain yang juga baik. Judment sampling umumnya memilih sesuatu atau seseorang menjadi sampel karena mereka mempunyai information rich (Mustafa, 2000).

\section{DISKUSI DAN PEMBAHASAN}

Dalam dunia praktis, pada kenyataannya bahwa seorang pengusaha dapat memiliki bisnis yang pada intinya ia tidak kuasai dari latar belakang pengalaman maupun pendidikan sebelumnya. Pengusaha tersebut dapat mencari seorang Chief Executive Officer (CEO) atau tim manajemen yang berpengalaman di bidangnya dan memiliki dasar pendidikan formal yang sesuai dengan bisnis yang didirikan, asalkan pengusaha memiliki jiwa kepemimpinan yang baik dan kemampuan berinovasi. Namun hal ini sering kali menjadi salah persepsi, seharusnya dapat dibedakan istilah antara pengusaha atau pelaku usaha dengan investor atau pemodal. Pada dasarnya, investor dapat menunjuk seorang CEO untuk menjalankan usahanya tanpa harus memiliki kemampuan atau pengalaman di bidang yang sama, dan ketika ada peluang baik ia akan berinvestasi. Sedangkan pengusaha atau pelaku usaha memerlukan adanya pemahaman mengenai bidang usaha yang digelutinya.

Pendapat tersebut tentunya masih harus diuji lebih lanjut. Dalam praktik bisnis sebenarnya masih memungkinkan pengusaha ataupun CEO yang belum berpengalaman di bidang bisnis yang digelutinya, bahkan tidak memiliki pendidikan formal yang sesuai dengan bisnis yang dijalani namun dapat sukses menjalankan bisnisnya. Contoh kasus diangkat dari beberapa tokoh bisnis di bidang kesehatan yang ada di Indonesia sebagai berikut.

Boenjamin Setiawan bersama 5 saudaranya mendirikan perusahaan farmasi, Kalbe Farma, pada 1966. Beliau meraih gelar dokter di Universitas Indonesia, kemudian melanjutkan studinya di University of California dan berhasil meraih gelar Ph.D di bidang farmakologi. Keahliannya pada farmakologi dan farmakinetiks. Saat ini perusahaan yang dipimpinnya menjadi perusahaan farmasi terbesar di Indonesia, bahkan di Asia Tenggara. Beliau menggabungkan beberapa perusahaan ke dalam Kalbe Group, antara lain: Kalbe Farma, Dankos Laboratories, dan Enseval Putra Megatrading. Perusahaan juga mengakuisisi Bintang Toedjoe dan mendirikan perusahaan riset dan pengembangan bekerja sama dengan Morinaga, PT. Innogene Kabiotect Pte., Ltd. Beliau juga menjabat sebagai pengurus Gabungan Pengusaha Farmasi Indonesia (Admin, 2013). Komitmennya sangat nyata dalam industri yang dipimpinnya dengan memproduksi obat generik berlogo (OGB) dan mengakuisisi beberapa perusahaan dalam mempertahankan kinerja berkesinambungan.

Ferry Abidin Soetikno, generasi kedua PT Dexa Medica, perusahaan farmasi yang ekspansif di Indonesia. Perusahaan beroperasi sejak 1969. Beliau adalah tamatan ITB jurusan Teknik Kimia dan melanjutkan ke Washington University, St. Louis jurusan Teknik Kimia dan University of Pittsburgh untuk pemasaran dan perencanaan strategis. Beliau pernah bekerja di KC Pharmaceuticals Inc., Pomona, Kalifornia hingga menduduki posisi sebagai Chief Operating Officer. Berbagai penghargaan pernah diraihnya. Inovasi yang dilakukan salah satunya dengan mengeluarkan produk Stimuno. Perusahaan melakukan ekspansi ke pasar ASEAN dan Afrika dan salah satu produknya, Boska, 
terkenal di Nigeria (AnneAhira.com). Kemampuannya berinovasi dengan mengembangkan produk live saving.

Charles Saerang adalah generasi ketiga dari Nyonya Meneer, perusahaan jamu PT Nyonya Meneer, yang berdiri sejak 1919. Beliau memperoleh gelar Bachelor of Science dari Business School Miami University, Ohio, Amerika Serikat. Beliau meraih gelar doktor ilmu pemasaran di Universitas Kensington, AS, 1981. Dalam perjalanan bisnis keluarganya, sempat terjadi perseteruan antarkeluarga. Beliau dipercaya untuk meneruskan dan mengelola usaha keluarga. Di bawah kepemimpinannya perusahaan berkembang dan melakukan ekspansi hingga ke Asia, Eropa, dan Amerika. Tahun 2000 perusahaan membuat terobosan dengan mengeluarkan produk fitofarmaka (obat dari tumbuhtumbuhan dan lulus uji klinis) bermerek Rheumaneer. Beliau juga menjabat sebagai pengurus Gabungan Pengusaha Jamu Indonesia. Beberapa penghargaan dalam dan luar negeri juga pernah didapat (Wikipedia, 2013). Komitmennya dalam industri adalah mengembangkan dan memperluas pasar jamu di pasar dalam negeri dan luar negeri.

Martha Tilaar adalah seorang pengusaha wanita di bidang kosmetika dan jamu dengan nama dagang Sariayu. Bekerja sama dengan PT Kalbe Farma membuat perusahaan kosmetika dan jamu PT Martina Berto. Perusahaan telah berdiri sejak 1977. Sebagai lulusan IKIP dan mendapat gelar doktor (honoris causa) di bidang fashion and artistry, beliau juga memiliki usaha kerajinan di Sentolo, Yogyakarta, dan memiliki Kampung Jamu Organik di Cikarang, Bekasi. Penghargaan nasional dan internasional pernah didapatkan oleh perusahaan. Pada 1993 perusahaan mengakuisisi pabrik kosmetik PT Cedefindo sebagai manufaktur kontrak untuk internal dan eksternal. Tahun 1996 perusahaan menjadi pabrik kosmetik pertama di Indonesia yang memperoleh 9001 certification. Pada ISO 2000 perusahaan ini menjadi satu-satunya pendiri Global Compact PBB dari Asia, juga mendapatkan sertifikat ISO 14001 dan sertifikat GMP: CPKB (Cara Produksi kosmetika Yang Baik) dan CPOTB (Cara Produksi Obat Tradisional Yang Baik). Beberapa penghargaan pernah didapat beliau. (Wikipedia, 2013).

Eddie Lembong, sebagai pemilik sekaligus pendiri PT. Pharos Indonesia pada 1971. Lulusan farmasi dan melanjutkan pendidikannya sehingga bergelar apoteker. Eddie Lembong memelopori penerapan GMP (Good Manufacturing Practice) dalam industri farmasi di Indonesia, 1972, yaitu suatu cara pendekatan baru dalam membuat obat yang bermutu, baik, dan terjamin. Juga diciptakannya konsep bioavailibility, metode untuk membuktikan bahwa obat yang mengandung zat berkhasiat sama tidak selalu mempunyai kemampuan pengobatan sepadan. Falsafah hidupnya, long life study, diterapkan dalam perusahaan. Ada beberapa perusahaan asing yang memberi kepercayaan pada Pharos untuk memproduksi obat mereka, di antaranya The Wellcome Foundation Ltd., Inggris, untuk tablet Lanoxin, obat penyembuh sakit jantung. Inovasi lainnya yang berhasil dilakukan adalah Pharolit $200-$ obat diare berbentuk bubuk dan Ardivit -kaplet berselaput gula dengan kandungan multivitamin dan mineral (Anonim, 2008).

Tan Eng Liang adalah generasi kedua dari perusahaan farmasi Soho. Perusahaan didirikan sejak 1946. Beliau mulai terjun ke bisnis farmasi sejak kepulangannya ke Indonesia dari Jerman pada 1976. Saat itu ia baru saja menyelesaikan pendidikannya dengan meraih gelar master di bidang fisika. Saat itu ayahnya, Tan Tjhoen Lim (dikenal sebagai Tan Senior), mengajaknya untuk rapat atau sekadar bertemu dengan para mitra bisnis di dalam dan luar negeri. Belakangan ia ditempatkan di bagian logistik. Alasannya, sebagai master di bidang fisika juga programming, ia bisa membuat sistem logistik bagi perusahaan. Soho mulai beranjak naik ketika ia memimpin perusahaan yang kini terdiri dari empat unit usaha (PT Soho Industri Pharmasi, PT Ethica Industri Farmasi, PT Parit Padang, dan PT Global Ritel Inti). Sebelum 1995, Soho tak memiliki strategi pemasaran yang modern. Saat itu yang banyak dilakukan perusahaan adalah aktivitas penjualan saja. Maklum, Soho belum memiliki profesional yang andal dan berpengalaman di bidang farmasi. Strategi pemasaran produk berbasis herbal melalui simposium pertama kali dilakukan tahun 1995. Saat itu Soho memelopori pemasaran produk herbal dengan cara etiket di Indonesia. Ketika kepemimpinan Soho beralih kepada Tan Eng 
Liang tahun 1997, Soho mulai menjadi perusahaan yang modern. Ia menghendaki Soho tak sekadar bertahan, melainkan harus pula tumbuh sehat dan melakukan lompatan-lompatan spektakuler. Menurut Tan Eng, hal pertama yang dipikirkan adalah SDM dan informasi. Pembenahan besar berikutnya adalah diterapkannya konsep Balanced Scorecard (BSC) pada 2005. Alasan Tan Eng, hal ini juga menyangkut perubahan budaya dan cara kerja perusahaan (Majalah Swa, 2009).

Kahar Tjandra, seorang pengusaha dan dokter asal Indonesia. Lulusan sekolah kedokteran di FKUI, Jakarta. Setelah lulus kedokteran, ia melanjutkan spesialisasi laboratorium. Sempat menjadi dokter di Departemen Kesehatan sebelum masuk wajib militer di RPKAD dan bekerja di RSCM, Jakarta, selama 20 tahun sambil menjadi dosen di FKUI. Pada 1967 ia mulai terjun ke dunia bisnis dengan membuka Apotek Mahakam, kemudian mendirikan PT Mahakam Beta Farma yang memproduksi obat antiseptik dengan merek dagang Betadine. Untuk melengkapai bisnisnya dibangun Laboratorium Klinik Utama, Johar Exclusive Clinic, PT Daya Muda Agung yang bergerak di bidang distributor obat dan snack, PT Garis Kreasi Hijau yang mengerjakan percetakan kardus untuk toko kue yang juga dimilikinya, Rumah produksi untuk mendokumentasikan acara-acara di Hotel Grand Mahakam, PT Beta Gasindo Agung yang memproduksi gas untuk kebutuhan medis, serta PT Inkenas Agung yang meluncurkan saus, sirup, kecap, dan vetsin. Toko kuenya Le Gourmet menjadi toko kue papan atas yang produknya banyak digemari oleh pejabat-pejabat negara. Saat ini total karyawannya diseluruh lini bisnis berkisar 2.000-3.000 orang. Selain memiliki apotek, klinik, perusahaan obat, dan perusahaan makanan-minuman, Tjandra juga menjadi pemilik hotel butik Grand Mahakan. Melalui Yayasan Dr. Kahar Tjandra, Tjandra menyisihkan sebagian penghasilannya untuk memberi beasiswa kepada anak asuhnya (Wikipedia, 2013).

Gideon Haryono, saat memutuskan untuk membuka usaha apotek yang buka selama 24 jam di Yogyakarta, sama sekali tidak mengawali dengan riset pasar. Beliau hanya mengandalkan nalurinya sebagai seorang pebisnis. Dibuka 24 Oktober 2002, jumlah pengunjung apotek terus mengalami peningkatan. Keberhasilan pengalaman ini memacu semangatnya untuk mendirikan apotek di tempat lain dengan brand Apotek K-24. Pada 2003, tepatnya pada 24 Maret dan 24 Agustus, dibuka dua outlet K-24 lagi di kawasan Jl. Gejayan dan Jl. Kaliurang. Menurut Gideon, ia tidak mengira jika potensi pasar apotek di Jogja dan Semarang, ternyata masih sedemikian besarnya. Ia mengaku omzet setiap outlet yang dikelolanya terus menunjukkan angka kenaikan. Saat ini, setiap outlet rata-rata per bulan, berhasil mencatat transaksi antara 350-500 items obat, dengan nilai penjualan antara Rp250-300 juta. Gideon mengaku tidak mengambil keuntungan besar dari obat yang dijualnya. Ia mengambil keuntungan dari omzet penjualan (TamanDewi, 2012).

Mochtar Riady adalah pendiri Grup Lippo. The Magic Man of Bank Marketing sudah bercitacita menjadi seorang bankir di usia 10 tahun namun ayahnya tidak mendukung karena profesi bankir menurut ayahnya hanya untuk orang kaya, sedangkan kondisi keluarga mereka saat itu sangat miskin. Oleh mertuanya, Mochtar Riady diserahi tanggung jawab untuk mengurus sebuah toko kecil. Dalam tempo tiga tahun ia telah dapat memajukan toko mertuanya tersebut menjadi yang terbesar di kota Jember. Kemudian beliau pindah ke Jakarta dan bekerja di sebuah CV di jalan Hayam Wuruk selama enam bulan, kemudian ia bekerja pada seorang importir, di waktu bersamaan ia pun bekerja sama dengan temannya untuk berbisnis kapal kecil. Sampai saat itu, Mochtar Riady masih sangat ingin menjadi seorang bankir, di setiap kali bertemu relasinya, ia selalu mengutarakan keinginannya itu. Suatu saat temannya mengabari dia jika ada sebuah bank yang lagi terkena masalah dan menawarinya untuk memperbaikinya, Mochtar Riady tidak menyia-nyiakan kesempatan tersebut walaupun saat itu dia tidak punya pengalaman sekalipun. Mochtar Riady berhasil meyakinkan Andi Gappa, pemilik Bank Kemakmuran yang bermasalah tersebut sehingga ia pun ditunjuk menjadi direktur di bank tersebut. Pada hari pertama sebagai direktur, Riady sangat pusing melihat balance sheet. Dia tidak bisa membaca dan memahaminya namun dia pura-pura mengerti di depan pegawai akunting. Lalu, sepanjang malam dia belajar untuk memahami balance sheet tersebut, namun sia-sia. Kemudian, dia minta tolong kepada temannya yang bekerja di Standar Chartered Bank untuk mengajarinya. Tetapi dia masih belum mengerti. Akhirnya, dia berterus terang kepada para pegawainya dan Andi Gappa, 
pemilik bank. Tentu saja mereka sangat terkejut mendengar pengakuan itu. Riady pun meminta diberi kesempatan mulai bekerja dari dasar. Andi Gappa menyetujuinya. Riady bekerja mulai dari bagian kliring, cash dan checking account. Dia menggunakan kesempatan itu bekerja sambil belajar dengan baik. Hanya dalam satu bulan, ia pun mengerti tentang proses pembukuan. Dia pun membayar seorang guru privat, yang mengajarinya akuntansi. Kemudian pindah ke Bank Buana tahun 1964 dan setelah menyelamatkan Bank Buana tahun 1966, ia bergabung dengan BCA pada 1975 dengan meninggalkan Bank Panin, lalu membeli sebagian saham di Bank Perniagaan Indonesia milik Haji Hasyim Ning pada 1981. Pada 1989, bank ini melakukan merger dengan Bank Umum Asia dan semenjak saat itu lahirlah Lippobank. Inilah cikal bakal Grup Lippo. Usaha yang dimiliki oleh Grup Lippo: pertama, jasa keuangan yang meliputi perbankan, investasi, asuransi, sekuritas, manajemen aset dan reksadana; kedua, properti dan urban development; ketiga, pembangunan infrastruktur seperti pembangkit tenaga listrik, produksi gas, distribusi, pembangunan jalan raya, pembangunan sarana air bersih, dan prasarana komunikasi; keempat, bidang industri yang meliputi industri komponen elektronik, komponen otomotif, industri semen, porselen, batu bara dan gas bumi; kelima, bidang jasa yang meliputi teknologi informasi, bisnis ritel, rekreasi, hiburan, hotel, rumah sakit, dan pendidikan. Di bidang kesehatan ia membangun rumah sakit untuk kelas atas di Lippo Karawaci bekerja sama dengan Gleneagles Hospital yang berbasis di Singapura (Wikipedia, 2013). Siloam Hospitals saat ini berkembang pesat. Legacy yang diciptakan saat ini adalah Mochtar Riady Institute of Nanotechnology (MRIN) dan Mochtar Riady Comprehensive Cancer Center (MRCCC). Dia memperoleh gelar doktor kehormatan di bidang hukum (Wikipedia, 2013).

Sjakon G. Tahija mendirikan PT Austin Nusantara Jaya bersama kakaknya, George Tahija, dan mempunyai kepemilikan saham di Arc Exploration Limited, eksplorasi pertambangan emas. Selain itu PT Austin Nusantara Jaya juga bergerak dalam berbagai bisnis usaha dan mempunyai banyak anak perusahaan. PT Austin Nusantara Jaya dengan bendera PT ANJ Agri bergerak dalam bisnis perkebunan kelapa sawit dengan total luas area mencapai 32.000 hektar. PT ANJ Agri mempunyai beberapa anak perusahaan antara lain PT Sahabat Mewah dan Makmur yang beropreasi di Belitung, PT Ondop Perkasa Makmur beroperasi di Sumatera Utara, PT ANJ Agri Papua yang beroperasi di Papua, PT Kayung Agro Lestari beroperasi di Kalimatan Selatan, dan PT Austindo Aufwind New Energy. PT Austindo Aufwind New Energy yang didirikan pada 2008 merupakan usaha patungan antara PT ANJ Agri dengan perusahaan asal Jerman Aufwind Schmack Group. Saat ini PT Austindo Aufwind New Energy sedang berkonsentrasi dalam pembangunan dan pengembangan pabrik biogas di Belitung. Selain itu PT Austin Nusatara Jaya juga memiliki 100\% saham dari PT Gading Mas Indonesian Tobacco. Perusahaan yang berlokasi di Jember, Jawa Timur, bergerak dalam bidang pengolahan tembakau untuk cerutu dan rokok dan menjualnya ke pasar di Eropa. Poada 2010 lalu PT Gading Mas Indonesian Tobacco melakukan ekspansi pasar ke Cina. Di bidang kesehatan melalui ANJ HealthCare membuka Klinik Mata Nusantara yang beroperasi di beberapa daerah di Jakarta. Di bidang keuangan dan investasi keuangan, PT Austindo Nusantara Jaya berkolaborasi dengan beberapa perusahaan investasi kelas dunia seperti JP Morgan dan Fidelity mendirikan PT ANJ Finance. Pada periode 2009 lalu total aset perusahaan ini sudah mencapai angka Rp1 trilyun lebih. Selain itu PT Austindo Nusantara Jaya juga memiliki saham mayoritas di PT Asuransi Indrapura. Globe Asia’s pada Juni 2011 lalu menempatkan George Tahija \& Sjakon Tahija pada nomor 47 dari 150 orang kaya Indonesia. Total kekayaan kakak beradik Tahija itu mencapai lebi8h dari US\$560 juta (Leo, 2012).

Ronny Handoko, pendiri klinik dermatologi, Erha Clinic sejak 1999. Beliau adalah lulusan spesialis kulit dan bertahun-tahun membuka praktik. Inovasi yang dilakukan Erha Clinic, tidak hanya kulit. Mereka mengembangkan produk layanan rambut, aphotecary, dan konsultan manajemen medis. Memulai produk OTC sejak 2007, Erha Clinic tampil dengan konsep berbeda dengan mengusung konsep hotel butik. Kelebihan Erha Clinic adalah memiliki laboratorium dan meracik obat sendiri untuk pasiennya. Tahun 2006 Erha Clinic akan meningkatkan ekspansinya dengan membuka hingga 40 cabang. Ini dimungkinkan karena klinik ini membuka diri bekerja sama dengan investor lokal. Tawaran tersebut kini mendapat respons yang cukup besar. Saat ini dikelola oleh anaknya, Richardo Handoko (Majalah Swa, 2006). 
Dari beberapa studi kasus tersebut, dapat dilihat bahwa kompetensi dan kesuksesan pengusaha tidak selalu mempunyai hubungan dengan tingkat pendidikan formal yang dilaluinya, contohnya adalah Martha Tilaar, Tan Eng Liang, dan Mochtar Riady. Seperti pengusaha lainnya, dengan latar pendidikan yang sama dengan bisnis yang digelutinya, kesuksesan dalam berbisnis didasari dari pembelajaran dan kemampuan berinovasi. Namun hubungan itu masih perlu dibuktikan pegaruhnya terhadap kemampuan berinovasi melalui penelitian secara empiris. Kompetensi pengusaha terhadap keahlian dan keterampilan sangat dibutuhkan, terutama dalam mengelola sumber daya yang ada, salah satunya adalah human capital.

Pengalaman seorang pengusaha untuk mampu melakukan inovasi, akan lebih tergantung pada kemampuannya melakukan inovasi itu sendiri dan merencanakannya; terhadap pengalaman budgeting, mungkin saja memiliki pengaruh namun karena sering kali tidak dibahas dalam studi kasus, maka bisa dikatakan bisa diabaikan; terkecuali dilakukan penelitian secara empiris. Pengalaman sering kali tidak berasal dari usaha atau bisnis yang sejenis dengan bisnis yang digelutinya, bahkan pengalaman sering kali didapatkan dari pengalaman di industri berbeda, contohnya adalah Martha Tilaar, Tan Eng Liang, dan Mochtar Riady.

Pembelajaran dalam melakukan inovasi adalah faktor yang kemungkinannya terbesar memiliki hubungan yang kuat dengan kemampuan berinovasi. Sebab seorang pengusaha harus dituntut berpikir kreatif, yang berasal dari pengalaman sebelumnya; juga ia harus berani mengambil risiko. Lompatan besar dalam karier yang dilakukan oleh Mochtar Riady dari dunia perbankan dan keuangan, lalu ke industri properti dan ritel dan kemudian ke industri kesehatan adalah proses pengambilan keputusan yang berisiko. Tentunya pengambilan risiko tidak hanya dilihat dari sisi kesuksesan yang hendak diraih namun bagaimana seorang pengusaha dapat melihat peluang yang ada dan mengambil peluang itu sambil memerhatikan risiko yang ada. Dengan melakukan pembelajaran yang benar, maka kemampuan berinovasi akan semakin besar.

Kesuksesan para tokoh dalam studi kasus tersebut, salah satunya dipengaruhi oleh kemampuan pengusaha dalam melakukan inovasi. Yang perlu dikaji dan ditelaah lebih mendalam (dan bisa dilakukan dalam penelitian empiris) adalah keterkaitan atau hubungan kemampuan berinovasi seorang pengusaha terhadap kesuksesan yang dicapainya. Kesuksesan yang dilihat dari lamanya ia dapat memimpin perusahaan dan perusahaan itu berjalan dengan baik, jumlah kekayaan yang dicapai melalui return on sales dan profit yang dihasilkan. Keterkaitan studi kasus dan pembahasan yang dilakukan dengan peluang di bidang industri kesehatan, pada intinya sama dengan pola atau model penelitian yang diangkat dalam paper ini. Sebab jika seorang pengusaha mampu melakukan inovasi dengan niat pembelajaran berinovasi yang tinggi dan didukung oleh pengalaman dan kompetensinya, dalam industri apapun yang digelutinya ia mampu mencapai kesuksesan sesuai komitmen yang ditentukan.

\section{SIMPULAN}

Keberhasilan seorang pengusaha dapat dipengaruhi oleh kemampuannya untuk melakukan inovasi sehingga dapat memposisikan diri dengan orang-orang yang lebih baik dari dirinya. Menjadi seorang inventor atau inovator saja tidak cukup, sebab ia harus dapat mengimplementasikannya dengan baik (Almawadi, 2013). Intinya, pengusaha yang sukses tidak hanya berdasarkan modal semata namun bagaimana ia mampu berinovasi melalui komitmen, proses, melakukan monitoring, memiliki tujuan dan dapat menjaga kinerja dengan baik.

Dalam artikel ini masih terdapat gap yang dapat dilakukan pada penelitian selanjutnya, yaitu bagaimana penelitian secara kuantitatif dapat dilakukan dengan mengacu dari pengambilan sampel 
dan pembahasan secara kualitatif terhadap tokoh-tokoh kesehatan di Indonesia. Proses selanjutnya yaitu mengaplikasikan model penelitian dan hipotesis yang telah dirancang pada penulisan ini menjadi penelitian secara empiris. Yang mungkin menjadi masalah dalam penelitian tersebut adalah mengidentifikasikan dan mengonfirmasikan antarsubvariabel dengan realitas yang ada, yang kemungkinan data yang diperoleh tidak mudah didapatkan. Dengan demikian model kuesioner atau pengidentifikasian subvariabel masih perlu didesain lebih hati-hati agar mendapatkan hasil yang baik dan benar.

\section{DAFTAR PUSTAKA}

Admin. (2013). Profil Boenjamin Setiawan - Pendiri PT Kalbe Farma Tbk. Retrieved Juni 20, 2013, from http://www.orangterkayaindonesia.com/profil-boenjamin-setiawan-pendiri-pt-kalbefarma-tbk/

Alegre, J., \& Chiva, R. (2007). Learning to Innovate. MITSloan Management Review , 49 No. 1, 1011.

Almawadi, I. (2013, Juni 19). Keberanian Mengambil Risiko Mengembangkan Bisnis di Daerah Rawan. Fenomena Woods Staton, p. 24.

. (2013, Juni 18). Woods Staton, Pengusaha Jejaring Waralaba McDonald's di Amerika Latin. Fenomena Woods Staton , p. 24.

AnneAhira.com. (n.d.). Kisah-sukses-pengusaha. Retrieved Juli 2, 2013, from http://www.anneahira.com/kisah-sukses-pengusaha.htm

Anonim. (2008). Apa dan Siapa - EDDIE LEMBONG. Retrieved Juni 6, 2013, from http://www.overseasthinktankforindonesia.com/wp-content/uploads/2008/05/apa-dan-siapaeddie-lembong.pdf

Claire-Woldt, L. (2005). Business Success: Entrepreneurial Visions from the Early Stage. Ann Arbor: ProQuest Information and Learning Company.

Hewitt-Dundas, N. (2006). Resource and Capability Constraints to Innovation in Small and Large Plants. Small Business Economics , 257-277.

Howard, J. (2009). Competent to Innovate: An Approach to Personal Development to Improve Innovation Competency in SME's. Knowledge to Innovate Initiative (K2i) .

Leo. (2012, Desember 29). Gurita Bisnis George Tahija (Menyorot PT Sumber Mineral Nusantara 2). Retrieved Juli 4, 2013, from http://petapolitik.com/news/gurita-bisnis-george-tahija-menyorotpt-sumber-mineral-nusantara-2/

Majalah Swa. (2006, Januari 26). Ekspansi Erha. Retrieved Juli 4, 2013, from http://swa.co.id/listedarticles/ekspansi-erha

Majalah Swa. (2009). www.swa.co.id. Retrieved from Soho: http://www.swa.co.id/swamajalah/sajian/details.php?cid=1\&id=8714

Mustafa, H. (2000). Teknik Sampling. Jakarta. 
Naidoo, S. (2008, Mei 7). Experience in An Entrepreneur is A Vital Requirement. The Mercury , p. 3.

Ramayah, T., Ahmad, N. H., \& Fei, T. H. (2012). Entrepreneur Education: Does Prior Experience Matter? Journal of Entrepreneurship Education , 65-81.

Reuber, R. (1994). Does Experience Make a Difference? The Impact of An Entrepreneur's Background on Her Firm. Canadian Women Studies , pp. 26-28.

Rognehaugh, R. (1998). The Managed Health Care Dictionary. Gaithersburg, MD: Aspen.

TamanDewi. (2012, Mei 17). Perjalanan Sukses Apotek K24. Retrieved Juli 4, 2013, from SuksesKerja-Usaha.Blogspot.com: http://sukses-kerja-usaha.blogspot.com/2012/05/perjalanansukses-apotek-k-24.html

Wikipedia. (2013, Juni 25). Charles Saerang. Retrieved Juli 4, 2013, from Wikipedia bahasa Indonesia: http://id.wikipedia.org/wiki/Charles_Saerang

. (2013, Mei 13). Martha Tilaar. Retrieved Juli 4, 2013, from Wikipedia bahasa Indonesia: http://id.wikipedia.org/wiki/Martha_Tilaar

. (2013). Wikipedia - The Free Encyclopedia. Retrieved Juli 4, 2013, from Mochtar Riady: http://id.wikipedia.org/wiki/Mochtar_Riady

. (2013). Wikipedia-The Free Encyclopedia. Retrieved Juli 4, 2013, from Kahar Tjandra: http://id.wikipedia.org/wiki/Kahar_tjandra 